Molise, H. (2021). Pathways to Mitigate Challenges of Learner Academic

Performance in a Grade 10 Economics Class in South Africa

\title{
Pathways to Mitigate Challenges of Learner Academic Performance in a Grade 10 Economics Class in South Africa
}

\author{
Habasisa V. Molise \\ Department of Human Sciences, School of Education \\ Sol Plaatje University, Kimberly, South Africa \\ habasisa.molise@spu.ac.za \\ Received : 2021-03-18 \\ Revised : 2021-04-26 \\ Accepted : 2021-05-01
}

$10.46303 /$ ressat.2021.5

\begin{abstract}
How to cite this paper: Molise, H. (2021). Pathways to Mitigate Challenges of Learner Academic Performance in a Grade 10 Economics Class in South Africa. Research in Social Sciences and Technology, 6(1), 83-101. https://doi.org/10.46303/ressat.2021.5

This is an Open Access article distributed under the terms of the Creative Commons Attribution 4.0 International license (https://creativecommons.org/licenses/by/4.0/).
\end{abstract}

\section{Abstract}

This paper aims to explore the pathways to mitigate challenges of learner academic (LAP) performance in a Grade 10 economics class in South Africa. The challenge of poor LAP has ushered a myriad of predicaments in schools globally. These predicaments include lack of teacher inclusion in decision making, inability to work cooperatively together, and lack of professional development opportunities geared towards LAP. The study was qualitative, with 15 participants chosen through purposeful sampling from one rural school in the ThaboMofutsanyane education district. This paper is couched in critical emancipatory research with emphasis on the emancipation of the teachers regarding pathways they can self-develop to mitigate the challenges of LAP. The focus group discussions were used to gather information regarding pathways to mitigate the challenges of LAP in schools. The study revealed that teachers possess a very equivocal and varying experience regarding the pathways to use to mitigate the challenges of LAP. The findings suggest that for successful implementation of pathways to mitigate the challenges of LAP, schools need to invest in training teachers for teamteaching and avail the necessary resources (both human and physical) to ensure effective quality teaching and learning exist in the school. The article recommends that schools should develop policy frameworks, together with relevant stakeholders, to guide novice teachers on the strategies they can use to mitigate the challenges of LAP in their classes.

Keywords: academic performance, critical emancipatory research, economics, participatory action research, pathways 
Molise, H. (2021). Pathways to Mitigate Challenges of Learner Academic Performance in a Grade 10 Economics Class in South Africa

\section{Introduction}

This paper aims to explore pathways to mitigate challenges of learner academic performance (LAP) in a Grade 10 economics class. The challenge of poor LAP has ushered a myriad of predicaments in schools globally (Asikhia, 2010; Trigueros, Aguilar-Parra, Lopez-Liria, Cangas, González \& Álvarez, 2020; Bojuwoye, 2009). These predicaments include lack of teacher inclusion in decision making, inability to work cooperatively together, and lack of professional development opportunities geared towards LAP (Warman, 2021; Van Wyk \& Alexander, 2010). Several studies confirm that most schools experience these predicaments (Hauge, 2019; Addow, Abubakar, \& Abukar, 2013; Molise \& Hlalele, 2014;). While such rhetoric may be rooted in the truth, other aspects are often forgotten in narratives about existing strategies (Risa \& Pupung, 2019) used to deal with the problem of poor academic performance in economics classes, generally. This is informed by the lack of developing pathways proposed by teachers and learners to mitigate challenges of learner academic performance (Tondeur, Aesaert, Prestridge \& Consuegra, 2018).

This study was conducted at one rural school in Thabo-Mofutsanyane Education District (TMED). The school was purposively selected because the author was working there as an economics teacher. The school had a total number of 390 learners who were schooling at that school. The author realized that the academic performance, especially by Grade 10 learners was not satisfactory, since a majority of the learners who were doing economics were not performing well academically. The author became worried about the situation and wanted to find out what could have been the challenges about learners' high failure rate in economics. What was more troubling, was the fact that parents were not coming to school when they were called to check their children's work, learners' absenteeism was very high, and teachers who were teaching economics were not motivated to teach the subject because they were claiming that it is difficult to them since they did not major in it. The workshops which were designed to professionally develop the teachers lacked capacitation about specific content changes which the teachers needed to be knowledgeable about and master. These changes led to teachers' frustration and burnout and left teachers having to battle with ways in which they can better teach the economics content. These challenges, motivated the author to conduct a study to explore the strategies the economics teachers can adopt to improve learner academic performance in Grade 10 economics class.

In a study on the benefits of group learning as a collaborative strategy in a diverse higher education context, the majority of the students reported having read wider and engaging deeper with the content as compared to their normal effort (Van Wyk \& Haffejee, 2017). Another study was conducted based on economic games as strategies to involve learners and make the subject fun to the learners. Students indicated that the use of games was the catalyst for creating a dynamic, vibrant learning environment that was conducive to deepening and internalizing their conceptual knowledge (Koenane, 2018; Soltero Lopez \& Lopez, 2020). From the above studies, it is evident that the authors used teaching strategies in their capacity to enhance learning in economics, but their approach seemed to romanticize it, they did not locate the issue within a theoretical framework (Dube \& Hlalele, 2018). The author acknowledges that there are many ways to conceptualize some suitable pathways to deal with 
Molise, H. (2021). Pathways to Mitigate Challenges of Learner Academic Performance in a Grade 10 Economics Class in South Africa

the problem (Tsotetsi \& Mahlomaholo, 2015). This article focuses on exploring the pathways to mitigate challenges of academic performance, strategies that economics teachers can adapt to overcome the challenges they face in the class.

\section{Research Questions}

The purpose of this study was to explore the pathways to mitigate the challenges of learner academic performance in a Grade 10 economics class. The following research questions were used to guide the research process:

- How can the establishment of a coordinating team serve as a pathway to mitigate the challenges of LAP?

- $\quad$ To what extent do the construction of a common vision through SWOT serve as a pathway to mitigate the challenges of LAP?

- Why should the drafting and implementation of the strategic plan serve as a pathway to mitigate the challenges of LAP?

- Which form of monitoring and evaluation of the strategic plan serve as a pathway to mitigate the challenges of LAP?

\section{Theoretical Framework}

In this paper, the author drew on literature that focused on the pathways to mitigate the challenges of LAP in a Grade 10 economics class. According to Stone (2017) pathways are strategies that bring key institutions together in effective partnerships grounded in extensive and intensive career development with teachers who are knowledgeable and effective in the delivery of a world-class technical curriculum. Similarly, Tsotetsi (2013) defines strategy as a plan for achieving something. Based on the above definitions, pathways, as used in this paper, refers to the self-initiated strategies that the teachers involved in teaching the same subject use as a collective to solve the challenges that threaten the teaching and learning environment. This includes establishing professional learning communities to share best practices through collaborative team-teaching to address the content knowledge misconceptions experienced.

\section{The coordinating team}

The study conducted by Tsotetsi (2013) on the implementation of professional teacher development policies, propounds that, for schools to mitigate challenges of learner academic performance, it is crucial to have in place a team that will work to achieve high standards and ensures that excellent endeavors to achieve high academic performance are a norm (Myende \& Nhlumayo, 2020; Risa \& Pupung, 2019). These teams should propose strategic initiatives to lead the school towards action-oriented goals. Several studies show that the establishment of a coordinating team is a cornerstone to mitigate challenges LAP initiative by an education institution (Myende, 2019; Molise, 2015; Bojuwoe, 2009; Msimanga, 2017). Shangase (2013) reports that a ministerial task team in South Africa was tasked to identify the challenges and areas that impacted negatively on the quality of teaching at schools and to propose mechanisms that could address these shortcomings. However, Koenane (2018) contends that problems related to education in South Africa are not simply the result of failures by current 
Molise, H. (2021). Pathways to Mitigate Challenges of Learner Academic Performance in a Grade 10 Economics Class in South Africa

policies, instead, problems are caused by existing strategies, and the way they are developed and implemented (Myende \& Chikoko, 2014; Samadi, 2021).

\section{Common vision and SWOT analysis}

Another study by Msimanga (2018) on the "teach and assess" as a strategy for effective teaching and learning in Economic and Management Sciences (EMS). The study revealed that the strategic planning for a school should involve a common vision, which is developed and owned by the principal and all relevant stakeholders, namely, parents, educators, non-teaching staff, learners, and the community in general (Sahito \& Vaisanen, 2018; Tsotetsi \& Mahlomaholo, 2015). All relevant stakeholders should participate constructively in the construction of a common vision. Tsotetsi (2013) contends that a vision owned by all relevant stakeholders can help to identify useful pathways and tactics that can be used to mitigate challenges of learners' academic performance (Molise \& Hlalele, 2014; Hayat, Shateri, Amini \& Shokrpour, 2020). Shangase (2013) argues that a vision cannot be realized if the principal fails to convert the vision into policy and practice (David \& Maistry, 2018; Warman, 2021). The author supports the view that the whole school community should be involved in the development of a vision, to ensure collective ownership. Msimanga (2017) agrees that a school needs a vision because the principal and governing body will change over time (Lane \& Caldis, 2018)., causing disruption, but the vision will remain (Kgari-Masondo \& Ngwenya, 2020; Falade, 2018).

\section{The strategic plan}

In yet, another study was conducted by Molise (2015) on the use of the case-study approach to improve learner academic performance in economics. The study revealed that economics teachers remain attending workshops that do not cater for professional development on the content knowledge, they teach in subjects outside their specialization and there are few opportunities for collaborative teaching because of costs relating to transportation of teachers from one school to the other. According to Msimanga (2017), doing a SWOT analysis helps the school to move towards its vision, through practical and concrete projects. The SWOT analysis should indicate priorities chosen by education practitioners (Samadi, 2021; Nja \& Obi, 2019; Mashego, 2012). Tsotetsi (2013) suggests that some modus operandi should be developed to bind together all three factors, namely, vision, SWOT analysis, and priorities, to formulate an action plan that is in line with the mission of the school. The SMT needs to work collaboratively with staff, learners, and parents to ensure the pathways work ( $\mathrm{Nja}$, Cornelius-Ukpepi \& Orim, 2019; Akinsolu, 2010). The involvement of relevant stakeholders in setting priorities is an integral part of the success of the strategic plan geared towards challenges to mitigate LAP (Ntibi \& Neji, 2018; Myende \& Chikoko, 2014; Tsotetsi, 2013).

\section{Monitoring and evaluation}

A study aimed to design a strategy to enhance professional curriculum practice (PCP) for a Grade 9 economic and management sciences class (EMS) at a school in the Thabo Mofutsanyana District. Moloi (2018) asserts that to ensure that the strategy for PCP succeeds, 
Molise, H. (2021). Pathways to Mitigate Challenges of Learner Academic

Performance in a Grade 10 Economics Class in South Africa

the team has to establish mechanisms to monitor and evaluate progress (Hayat, Shateri, Amini \& Shokrpour, 2020; Molise \& Hlalele, 2014; Warman, 2021). Progress should be monitored by all relevant stakeholders (Darling-Hammond, Flook, Cook-Harvey, Barron \& Osher, 2020; Mahlomaholo, 2014). Mlebese et. al, (2019) contend that hard work, patience, a clear purpose for the coordinating team, and open communication among team members (Azevedo, 2018) contribute to success. Similarly, there must be clear roles and responsibilities, strong relationships among the coordinating team, and a willingness to share information and listen to one another (Malebese et. al, 2019; Hsu \& Lin, 2020; Egalite \& Kisida, 2017; Samadi, 2021). The next section discusses the theoretical framing in which the study is couched.

\section{Critical emancipatory research}

The author positioned this paper by using critical emancipatory research (CER) as the theoretical lens (Haigh, Kemp \& Bazeley, 2019), based on its ability to advocate peace, hope, equality, team spirit, and social justice (Hutton, 2020; Nkoane, 2012). CER, as used in this paper, requires being committed to enabling people to question their status and the injustices prevalent in their communities (Duckworth \& Tett, 2019; Esau, 2013; Hlalele, 2014), while liberating them, meeting the needs of real-life and raising self-consciousness (Adebola, Tsotetsi \& Omodan, 2020; Makoelle, 2013). In pursuance, CER served as an emancipatory experience and provided the participants' space to contribute ideas freely through the encouragement of cordial relationships, tolerance of individual ideas, common consensus, love, and hope (Andrew\& Baker, 2020; Tshelane, 2013). CER contributed to building relationships and individual consciousness between learners and teachers (Dube \& Molise, 2018; Houdyshell \& Ziegler, 2020). CER enabled participants to provide mainly qualitative data through focus group meetings, which served the purpose of creating space and opportunity to use the participants' home language to create a non-threatening environment and encouraged them to speak freely without fear or intimidation (Halliday, Kern, Garrett \&Turnbull, 2019).

Throughout the information sessions we held as part of data generation, my role, as the author, was to facilitate the emancipatory process, through pathways to mitigate challenges of learners' academic performance. All the relevant stakeholders were engaged, and operated under equal power relations (Hlalele, 2018) and, therefore, owned the process of research, from identifying the research topic to collecting and analyzing data (Mahlomaholo, 2014). The aim of working together with the participants as a team was to create a space for the participants to be empowered as CER advocates (Dube \& Hlalele, 2018; Mashego, 2012). Thus, CER enabled me to listen to the participants and work with them to determine the pathways we used to mitigate the challenges of learners' academic performance.

CER is relevant to this paper in that it exposed and questioned hegemony and traditional power assumptions (Msimanga, 2017) held about relationships, groups, communities, societies, and organizations to promote social change' (Hutton, 2020). The change, in this case, was to ensure that the participants are not working through imposed strategies instead they developed their pathways to mitigate challenges of learner academic performance in a grade 10 economics class. 
Molise, H. (2021). Pathways to Mitigate Challenges of Learner Academic Performance in a Grade 10 Economics Class in South Africa

\section{Methods}

\section{Design}

Participatory action research (PAR) was used as a research design. By nature, the PAR research design adopted based on the premise that the people who are affected by a particular problem must be active in the research process so that they can determine the solutions to the identified problems (Adebola, Tsotetsi \& Omodan, 2020; Udvarhelyi, 2020; Nkoane, 2012; Pillay, 2018). The PAR process allowed for the participants to work together in teams to brainstorm ideas as a collective to identify problems relating to LAP, define the implications of such problems in education, put mechanisms in place to deal with the problems, and ensure that there if effective monitoring and evaluation to circumvent challenges of LAP (Lane \& Caldis, 2018; Pillay, 2015; Mahlomaholo, 2012). It also served as an archetype that created space for the research process which is emancipative, critical, transformative, and valued issues of social justice (Adebola, Tsotetsi \& Omodan, 2020) for the participants to brainstorm about self-initiated pathways they can use to mitigate challenges of LAP. PAR enabled the participants to investigate meaningful social topics, especially the challenges of LAP and mitigation strategies/pathways (Msimanga, 2017), by participating in research to understand the root causes of problems relating to LAP (Tshelane, 2013), and then took collective action to influence policies through the dissemination of their findings to policymakers and stakeholders about strategies to tackle LAP (Molise, 2015). PAR is deemed relevant in this study because the researcher and the participants were equally involved in the process (Dube \& Hlalele, 2018), they took shared responsibility for the outcome of the research endeavor (Wright, 2020). In other words, participation, research, and action were of major importance in such a partnership (Esau, 2013). This study was undertaken for educational purposes, which is to contribute new knowledge on the pathways to follow to mitigate the challenges of LAP. PAR also helped distill a distinctive feature of participation of those affected by the issue and their involvement in both asking and answering the action research question (Wright, 2020). The research was conducted in September 2012 at a rural school in Thabo-Mofutsanyana Education District.

\section{Participants}

A total number of 15 participants were purposively selected to participate in a study that sought to explore pathways to mitigate challenges of LAP in a Grade 10 economics class. Through purposive sampling, participants are selected according to what they already know about the field and because they have certain characteristics in common that relate to the topic of the study (Moloi, 2018). The reason for choosing purposive sampling is that qualitative research is more concerned with detailed and in-depth analysis than with statistical accuracy. Table 1 below presents data on the characteristics of the participants in terms of affiliation, gender, and age. 
Molise, H. (2021). Pathways to Mitigate Challenges of Learner Academic Performance in a Grade 10 Economics Class in South Africa

Table 1: Profile of the participants

\begin{tabular}{lllll}
\hline Pseudonym & Affiliation & Gender & Age & Grade/Subject \\
\hline Siza (Researcher) & University of the Free State & Male & $30-35$ & Economics \\
Pule (Teacher) & Deputy Principal & Male & $45-50$ & Physical Science \\
Lemza (Teacher) & HoD-Commercial subjects & Male & $40-45$ & Economics \\
Gloria (Teacher) & Senior teacher-Economics & Female & $55-60$ & Economics \\
Alice (Teacher) & PL1-Economics & Female & $40-45$ & Economics \\
Tshepo (Lecturer) & Economics Education & Male & $40-45$ & Economics \\
Mdu (LF) & Subject advisor-Economics & Male & $55-60$ & Economics \\
Boka (Facilitator) & Kagiso-Trust & Female & $40-45$ & Accounting \\
Hlaps (RCL) & RCL President & Male & $17-18$ & Grade 12 \\
Mpho (Learner) & Grade 10 Economics & Males & $15-16$ & Grade 10 \\
Thiza (Learner) & Grade 11 Economics & Female & $16-17$ & Grade 11 \\
Siza (Learner) & Grade 12 Economics & Female & $17-18$ & Grade 12 \\
Isaac (Learner) & Grade 10 Economics & Females & $15-16$ & Grade 10 \\
Jane (Learner) & Grade 11 Economics & Male & $16-17$ & Grade 11 \\
Thabo (Learner) & Grade 12 Economics & Male & $17-18$ & Grade 12 \\
\hline
\end{tabular}

The informed consent was obtained from the participants and they were also advised that they can withdraw their participation at any time. The participants were given an assurance that all the information they share will be kept confidential and it is used solely to make sense of the pathways to mitigate LAP. Pseudo names are used to protect identities.

\section{Instruments}

The data generation instruments used in this study included the teacher observation guide (TOG) and teacher interview guide (TIG) (Makoelle, 2013; Koenane, 2018; Falade, 2018). The purpose of this study was to explore the pathways to mitigate the challenges of learner academic performance in a Grade 10 economics class. Data obtained from expert opinions and the results of the literature reviews were taken as a base to prepare the TOG and TIG (Makoelle, 2013; Egalite \& Kisida, 2017). In the context of this study, the use of TOG involved two observers who observed three different teachers' lessons. One of the observers was the researcher and the other observer was the expert on the subject (Falade, 2018). Both the observers wrote reflective journals of the teachers' lessons about economics content and participated in a focus group discussion setting (Adebola, Tsotetsi \& Omodan, 2020). Concurrently, the author kept observational and reflective notes during each phase, met weekly (Dube \& Hlalele, 2018) to discuss the pathways to mitigate the challenges of LAP, and reviewed recordings of lessons presented by teachers. In operationalizing the TIG, the following questions were posed to the participants during the interviews to gather their in-depth understanding of the challenges of LAP and pathways they can use to mitigate these challenges: (1) How can the establishment of a coordinating team serve as a pathway to mitigate the challenges of LAP? (2) To what extent do the construction of a common vision through SWOT serve as a pathway to mitigate the challenges of LAP? (3) Why should the drafting and implementation of the strategic plan serve as a pathway to mitigate the challenges of LAP? (4) Why should monitoring and evaluation of 
Molise, H. (2021). Pathways to Mitigate Challenges of Learner Academic

Performance in a Grade 10 Economics Class in South Africa

the strategic plan serve as an important pathway to mitigate the challenges of LAP? The draft form was presented to the one academic who was an expert in the field to analyze the guide objectively.

\section{Data collection}

Data were collected using observations and interviews. Qualitative observation deals with major sensory organs and their functioning-sight, smell, touch, taste, and hearing while a qualitative interview is a more personal form of research compared to questionnaires (Braun \& Clarke, 2006; Makoelle, 2013; Andrew \& Barker, 2020). The interviewer can probe or ask follow-up research questions of the interview participant. The observations enabled the researcher to see the participants' involvement in the PAR process to make sense of their feelings and emotions regarding the pathways to mitigate LAP (Wright, 2020; Braun \& Clarke, 2006). The participants' reactions were recorded in the observation schedule by the researcher with the assistance of another participant to ensure the reliability and validity of the observations (Duckworth \& Tett, 2019). The interviews were used to gather in-depth (Braun \& Clarke, 2006) views of the participants about the pathways to mitigate the challenges of LAP. The following challenges emerged from the four research questions anchoring the. Research question one included challenges such as teachers working in isolation, lack of content knowledge, and inability to take concrete decisions. Research question two included challenges such as teaching without a purpose and the inability to develop and contribute to the school vision. Research question three included challenges such as lack of passion, lack of problemsolving skills, and high failure rate. Research question four included challenges such as, lack of clear strategies, inability to set clear priorities, lack of commitment, and unwillingness to seek help. The generated data from lesson observations and interviews were recorded using audiorecorder and were later transcribed verbatim. The participants were also given Pseudonyms to protect their identity and assured that the generated data will only be utilized for this study with no form of disclosure to the third parties.

\section{Data analysis}

Thematic analysis (TA) was used to analyze the generated data (Braun \& Clarke, 2006). Reflexive thematic analysis theory as used in this study was found to be appropriate to analyzing qualitative data to answer broad or narrow research questions about people's experiences, views and perceptions, and representations of a given phenomena (Dube \& Hlalele, 2018). This process was originally developed for psychology research by Virginia Braun and Victoria Clarke (Msimanga, 2017; Makoelle, 2013; Adebola, Tsotetsi \& Omodan, 2020). It is an approach for categorizing, reporting, organizing, defining, and analyzing themes found within a data set (Adebola, Tsotetsi \& Omodan, 2020). The thematic analysis made it easy for the author to analyze data because it makes data to be easily understood, it provides a conveniently detailed, especially when summarizing critical concepts of a huge data set (Makoelle, 2013). The researcher closely examined the data to identify common themes - topics, ideas, and patterns of meaning that came up repeatedly. The following steps proposed by Braun \& Clarke (2006) were followed. The first step involved data immersion and thorough readings and viewings to create lists of initial ideas about the data. Second, a semantic approach (Braun \& Clarke, 2006) 
Molise, H. (2021). Pathways to Mitigate Challenges of Learner Academic

Performance in a Grade 10 Economics Class in South Africa

was employed to generate an initial coding scheme related to previous research, research questions of the study, and theoretical frameworks for determining pathways to mitigate the challenges of LAP. Third, codes were sorted into possible themes, compared and adjusted based on relevant data, and thematic relationships were considered. Fourth, themes and examples were reviewed within codes and across the entire data set. Fifth, themes and definitions were created using clear descriptive language and illustrative excerpts and organized as findings in this study.

\section{Results and Discussion}

The following sections present and discuss findings from the focus group discussions on the pathways followed to mitigate the challenges of poor learner academic performance in a Grade 10 economics class.

The analysis of data from the focus group discussions resulted in four major themes, namely, (1) coordinating team, (2) common vision and SWOT analysis, (3) Strategic Plan, and (4) monitoring and evaluation. These themes and their key-related codes are summarized in Table 2 below and are hereafter described with a key representative from participant quotations. The results are also interpreted in terms of the research questions of the study.

Table 2: Themes and Related Key Codes

\begin{tabular}{|c|c|c|}
\hline Themes & & Key Related Codes \\
\hline Theme 1: Coordinating team & $\begin{array}{l}\bullet \\
\bullet \\
\bullet\end{array}$ & $\begin{array}{l}\text { Work is much easier } \\
\text { People work together } \\
\text { Remained without knowledge } \\
\text { Concrete decisions } \\
\text { Benefit learners greatly }\end{array}$ \\
\hline Theme 2: Common vision and SWOT analysis & $\bullet$ & $\begin{array}{l}\text { Live for a purpose } \\
\text { Developing vision for the school }\end{array}$ \\
\hline Theme 3: Strategic plan & . & $\begin{array}{l}\text { Realize the strength } \\
\text { Defeating challenges in education } \\
\text { Solving of problems } \\
\text { Clear plan } \\
\text { High failure rate }\end{array}$ \\
\hline $\begin{array}{l}\text { Theme } 4 \text { : Monitoring and evaluation of the } \\
\text { action plan }\end{array}$ & $\bullet$ & $\begin{array}{l}\text { Checking of issues to address } \\
\text { urgently } \\
\text { Keep priorities straight } \\
\text { Separate play-time from school } \\
\text { work } \\
\text { Asking for help }\end{array}$ \\
\hline
\end{tabular}


Molise, H. (2021). Pathways to Mitigate Challenges of Learner Academic Performance in a Grade 10 Economics Class in South Africa

\subsection{Pathway 1: Establishment of the coordinating team}

In this section, I respond to the first research question, that is, how can the establishment of the coordinating team serve as a pathway to mitigate challenges of LAP. Tsotetsi (2013) that working as a team is a cornerstone for any pathway to mitigate challenges of learner academic performance initiatives within an educational institution (Shangase, 2013; Myende \& Nhlumayo, 2020). For schools to enhance LAP it is crucial to have in place a team that will work towards high standards and that excellent LAP endeavors are a norm (Tsotetsi \& Mahlomaholo, 2015). These teams come up with strategic initiatives that will lead the school towards actionoriented goals.

The study found that the establishment of the coordinating team could greatly help mitigate the challenges of LAP if teachers realize the importance of working together as a team. Teamwork is very important because if teachers work together to assist one another in terms of lesson planning and share best practices on how to approach the content, their work becomes easier, ultimately improving their teaching styles. The participants echoed the suggestion in the following utterances:

Lemza said:

Today I realized that the work is much easier if people work together, when we work together we can achieve more. We need to assist one another in planning our lessons though some of us are selfish and want to receive certificates of performance alone.

Gloria added:

This author is compared to Messiah who came at the time when his presence is needed, as the school we are very grateful if it was not for this research we could have remained blind and without knowledge. We are left alone in our class to battle with the content without any help from our subject advisor. Your suggestion is highly welcome Sir!

Gloria supported the two participants' views:

The Department needs to support us as teachers, they must walk out of their comfortzones. Our LFs need to come regularly to our schools to support us. Some of the workshops we attend are useless because we focus on many files and told about the results. How can our learners perform if we are not supported?

The sentiments by the participants above indicate that the support that they receive from their subject advisors should cover training on content knowledge. And that continuous visits by LFs to schools create opportunities for teachers to seek help instead of when they all called in one workshop. To this end, there were suggestions that the subject advisors should frequently visit school and support teachers regarding the content misconceptions they may have and share best practices on how to teach effectively to improve the academic performance of the learners. 
Molise, H. (2021). Pathways to Mitigate Challenges of Learner Academic

Performance in a Grade 10 Economics Class in South Africa

Gloria's view is enforced in Shangase (2013) who attests that a Ministerial Task Team in South Africa was constituted to identify the challenges and pressure points that impacted negatively on the quality of teaching in schools and proposed mechanisms that could address these. The task team noted that dealing with educational challenges requires collective efforts from both the school and the society at large. People working as a team can achieve more than those operating as separate entities or in isolation.

\subsection{Pathway 2: Construction of a common vision through SWOT analysis}

In this section, I respond to research question number two, which is, how can the construction of a common vision through SWOT analysis serve as a pathway to mitigate challenges of LAP? I begin by acknowledging that the construction of a common vision through SWOT analysis has played a pivotal role in ensuring that the teachers teach for a purpose and can realize their strength when dealing with the challenges of LAP. According to Msimanga (2017) that teachers should work together in developing the vision for their school and such a vision must be owned by all and reflected in the daily teaching and learning activities of the school (Molise, 2015). The foregoing argument is supported by Tsotetsi (2013) who argues that this approach emphasizes that for the school to be successful all its activities must be driven by its values and vision and that a thorough SWOT analysis must also be conducted to determine if the pertinent issues relating to strengths, weaknesses, opportunities, and threats in the various contexts of political, economic, social, and technological trends are identified, interpreted, and analyzed (Shangase, 2013).

The study found that the construction of a common vision was not done through SWOT analysis. While arguing for SWOT analysis to be done to formulate the vision of the school, I take cognizance of the view by Tsotetsi (2013) that teachers find themselves having to implement the school vision that they did not self-develop and difficult to understand. Despite that, teachers are expected to perform according to what the vision of the school stipulates, with no guidance provided to them on how they must incorporate the school's vision in day-to-day school activities. Cognizant of this, the participants appreciated the interventions provided by the school management in terms of strategies they can use to improve the academic performance of their learners but these strategies did not incorporate clear identification of their strength and weaknesses, opportunities which the school had and possible threats so that they can know what problems need to be prioritized and addressed. The participants commented as follows:

Lemza expressed the view that:

I agree, if you do not have a vision you are like someone who lives without a purpose. I am happy that we were allowed to give our inputs on the vision we will like to have for our school. Through the vision "raising the bar, leaving no child behind", I see how it is linked to our daily activities at the school. And that when we teach, we should make sure that all the learners benefit from our teaching.

Emphatically, Alice added:

Ohhh Yes! Today I am grateful that I had a say in developing the vision of our school. At least, we're able to identify the many opportunities we have as a school and the 
Molise, H. (2021). Pathways to Mitigate Challenges of Learner Academic

Performance in a Grade 10 Economics Class in South Africa

strengths that some of the teachers who present the same subject have, and how we could use them to our advantage.

The sentiments by the participants above emphasize the importance of involving teachers when formulation the vision of the school. And the vision needs to be unpacked so that the teachers can know how the vision links with day-to-day school activities. The teaching and learning activities should be incorporated into the school vision so that the vision can be realized.

The views of Lemza above are enforced in Shangase (2013) when he argues that the school's vision should be developed and owned by the principal and all major role-players, namely, parents, educators, non-teaching staff, learners, and the community in general. These roleplayers must participate constructively in the development of the vision of the school. From what the participants are saying, the vision cannot be realized if the school fails to convert the vision into policy and practice (Molise, 2015). The whole school community should in some way be involved in the development of a school's vision. The school has to have a clear direction and everyone has to have an idea about what the school is trying to do. Moloi (2018) affirms that for the effective management of the learners, the school vision should be clearly articulated and clarified to all educators and learners so that they can mitigate challenges of their performance using pathways they self-developed.

\subsection{Pathway 3: Drafting and implementing a strategic plan}

In this section, I respond to the third research question, that is, how can the drafting of the strategic plan serve as a pathway to mitigate the challenges of LAP? I acknowledge further that, a mere analysis of the strengths and weaknesses of the school, as well as the opportunities for and threats to the school, is pointless unless the relevant stakeholders (teachers and learners, etc.) come together to develop an action plan. As Molise (2017) argues that the coordinating team must be able to identify key priorities which emerge from the strategic plan (Molise, 2015), and such priorities should have a specific time frame in which they can be addressed, persons responsible identified, and the resources needed to be allocated (Msimanga, 2017).

The study found that the drafting of the strategic plan provided opportunities for teachers to be actively involved in decisions regarding the challenges they experience with LAP. The participants were able to inform the school management is the urgent challenges they were confronted with and what specific resources they needed for them to ensure that quality teaching and learning exist in the school. Though this may present the challenge as to who is best fit to see that all the challenges included in the strategic plan are spearheaded by people with the necessary capacity to solve them, the participants noted that if the teachers are tasked the responsibility to lead some of the activities in the strategic plan, it could be a way of ensuring collective ownership by all instead of these activities having to be led only by the principal and the school management team (SMT). Traditionally, the activities on the strategic plan of the school were always led by the SMT without the involvement of the teachers. The participants had the following suggestions:

Alice ascertained that: 
Molise, H. (2021). Pathways to Mitigate Challenges of Learner Academic

Performance in a Grade 10 Economics Class in South Africa

Honestly, am not so sure if we have a plan as the school to address our challenges. If we ever had, the plan is only known to the principal and the SMT because they do not communicate it to us. They need to include us when they do planning for the school because we the ones at the core of teaching the learners and we understand the challenges that make it difficult for the learners to perform.

While Gloria said:

In the past, we did not have a way to follow in solving our problems. I think the problem was we were just working without a plan in place. I have just realized that it is important to have a clear plan for us to address the high failure rate in our economics classes. I am happy that we can now achieve some of the things but not all of them at the same time but we going somewhere because we are allowed to lead some of the activities that we have planned for. The words echoed by the participants above indicate that a whole school's strategic planning is necessary where all the teachers are involved. The dates for the strategic planning should be communicated well in advance so that the teachers could plan for the things they would like to be on the plan. Both the participants agree that their involvement in informing the drafting of the strategic plan and liberty to lead some activities, served as a tool that enabled them to identify the challenges they had through a comprehensive strategic plan in place, detailing specific learner academic performance challenges to prioritize.

The words of Alice above are enforced in Msimanga (2017) who asserts that teachers should be at the center of leading some of the activities on the strategic plan, especially the activities which relate to daily teaching and learning activities. To this end, it can be suggested that a clear modus of Operandi must be formed to bind together all three factors, namely vision, SWOT analysis, and prioritization to formulate an action plan which is in line with the mission of the school. According to Tsotetsi (2013), a school can be said to function adequately, but a conscious action plan to eradicate weaknesses is an important pathway to support the vision for mitigating challenges of learner academic performance.

\subsection{Pathway 4: Monitoring and evaluation of the action plan}

In this section, I respond to the fourth research question, which is, how can monitoring and evaluation of the strategic plan serve as a pathway to improve LAP? I, thus acknowledge that effective and continuous monitoring and evaluation is a key component to the successful implementation of the strategic plan. Moloi (2018) alludes to the importance of continuous monitoring and evaluation of the strategic plan and indicates that it provides space to continually review the mechanisms in place to address the identified challenges. Similarly, Malebese, Tlali, and Mahlomaholo (2019) concur that frequent monitoring helps to identify the progress made and to check if the resources allocated both human and physical are drawn to sustain good academic performance.

The study found that continuous monitoring and evaluation of the planned activities is imperative and the participants acknowledged that not all activities can be solved at once. While this could present effective monitoring and evaluation challenges, the participants noted further the importance of frequently revisiting the action plan to check if the planned activities are being achieved or if they need extra resources and expertise to help improve the solutions 
Molise, H. (2021). Pathways to Mitigate Challenges of Learner Academic

Performance in a Grade 10 Economics Class in South Africa

they may have by changing roles in terms of persons responsible. It is also crucial that to keep track of the success of the implementation of planned activities through frequent monitoring and evaluation. The participants commented as follows:

Lemza had this to say:

We have learned that we have so many challenges and we are unable to solve them at the same time. In that way, we have to check those that are urgent, and which make learners fail.

Gloria added:

Sometimes learners are unable to keep their priorities straight. They cannot separate between playtime and school work. They always want to be reminded about studying and asking for help when we do not understand. Intensive monitoring of the learners' work needs to be done so we could check if they are progressing in their learning.

The participants' words above indicate that prioritizing the planned activities can go a long way in ensuring that the learners are supported in their academic activities. Frequent monitoring and evaluation of these activities need to be in place to check the progress that the people responsible to spearhead a particular activity are making and follow-up if the activities are effectively implemented.

Lemza and Gloria's views are enforced in Moloi (2018) when he stipulates that setting priorities should be about reconciling differences in the process of improving the academic performance of a learner. Mahlomaholo (2014) supports further that prioritization is an important component of an effective development program. In the school situation, prioritization helps SMTs to focus, giving room to maintain strengths and eradicate weaknesses in favor of better academic performance (Samadi, 2021).

\section{Value of the Study}

The study will benefit the existing body of knowledge in economics education. It could be used to help other schools with a similar problem to formulate pathways or strategies to improve LAP in Grade 10 economics classes. Participants in the study will have the opportunity to take pride in and enjoy the outcomes of the research to which they contributed.

\section{Conclusion}

The LAP presented various challenges throughout the educational class. However, problems related to education in South Africa are not simply the result of failures by current policies, although there are certainly instances in which policies need to be modified. Instead, problems are caused by existing strategies, and the ways they are developed and implemented. The move towards pathways to mitigate challenges of LAP presented various challenges and opportunities which need to be addressed from a scholarly point of view. The author noted that challenges such as lack of teacher inclusion in decision making, inability to work cooperatively together, and lack of professional development affect the effectiveness of pathways geared towards LAP. The author further suggested ways in which LAP using self- 
Molise, H. (2021). Pathways to Mitigate Challenges of Learner Academic Performance in a Grade 10 Economics Class in South Africa

initiated pathways can be improved. The author also argued throughout the paper, informed by CER, that there is a need to emancipate the teachers to help them devise strategies that can be used to tackle the challenges of LAP in their class.

The author recommends that for successful implementation of pathways to improve LAP, that schools need to invest in training teachers for team-teaching and avail the necessary resources (both human and physical). Lastly, schools should develop policy frameworks to guide novice teachers on the strategies they can use to mitigate the challenges of LAP.

The limitation of this study was that it was conducted using only one school in the ThaboMofutsanyana Education District. The study's purpose was to not provide a general outcome but to find and indicate specific outcomes regarding the pathways the participants' understudy can use to mitigate challenges of LAP in their school. To address the above limitation, the study needs to be conducted where more participants are included and more than one school be included. I further propose that a similar study be done using a different design and approach since this study was couched in participatory action research.

\section{References}

Addow, A. M., Abubakar A. H., \& Abukar, M. S. (2013). English language proficiency and academic achievement for undergraduate students in Somalia. International Journal of Educational Research, 2(2), 59-66. http//doi.org/doi:10.31901/24566322.2015/09.03.07

Adebola, O.O., Tsotetsi, C.T. \& Omodan, B.I. (2020). Enhancing Students' Academic Performance in University System: The Perspective of Supplemental Instruction. International Journal of Learning, Teaching, and Educational Research, 19(5), 217 230. https://doi.org/10.26803/ijlter.19.5.13.

Akinsolu, A. O. (2010). Teachers' and students' academic performance in Nigerian secondary schools: Implications for planning. National Institute for Educational Planning and Administration, 3(2), 86-103.

Asikhia, O. A. (2010). Students' and teachers' perception of the causes of poor academic performance in Ogun State secondary schools [Nigeria]: Implications for counseling for national development. European Journal of Social Sciences, 13, 228-242.

Andrew, J. \& Baker, M. (2020). For emancipation: A Marxist critique of structure within critical realism. Accounting, Auditing \& Accountability Journal, 33(3), 641-653. https://doi.org/10.1108/AAAJ-11-2019-4251

Azevedo, F. S. (2018). An inquiry into the structure of situational interests. Science Education, 102(1), 108-127.

Bojuwoye, O. (2009). Home-school partnership. A study of opinions of selected parents and teachers in Kwa-Zulu- Natal province, South Africa. Research Papers in Education, 24, 461-475. https://doi.org/10.1080/02671520802150004

Braun, V. \& Clarke, V. (2006) Using thematic analysis in psychology. Qualitative Research in Psychology, 3 (2). pp. 77-101"

Borge, M., Ong, Y. S., \& Rosé, C. P. (2018). Learning to monitor and regulate collective thinking processes. IJCSCL, 13(1), 61-92. https://doi.org/10.1007/s11412-018-9270-5 
Molise, H. (2021). Pathways to Mitigate Challenges of Learner Academic

Performance in a Grade 10 Economics Class in South Africa

Dube, B. \& Hlalele, D. (2018). Engaging critical emancipatory research as an alternative to mitigate school violence in South Africa. Educational Research for Social Change, 7(2), 74-86. http://dx.doi.org/10.17159/2221-4070/2018/v7i2a5

Dube, B., \& Molise, H. V. (2018). The church and its contributions to the struggle to liberate the Free State. Journal of Contemporary History, 43(1), 160-177. http//doi.org/10.18820/24150509

Duckworth, V., \& Tett, E. (2019). Transformative and emancipatory literacy to empower. International Journal of Lifelong Education, 38(4), 366-378. https://doi.org/10.1080/02601370.2019.1574923

David R \& Maistry SM (2018) The school economics textbook as programmatic curriculum: An exploited conduit for neoliberal globalization discourses. Journal of Education, 74, 32-46.

Darling-Hammond, L., Flook, L., Cook-Harvey, C., Barron, B., \& Dart, G., Nkanotseng, T., Chizwe, O., \& Kowa, L. (2010). Albinism in Botswana junior secondary schools: A double case study. British Journal of Special Education, 37(2), 77-85. https://doi.org/10.1111/j.1467-8578.2010.00465.x

Egalite, A. J., \& Kisida, B. (2017). The effects of teacher mismatch on students' academic perceptions and attitudes. Educational Evaluation and Policy Analysis, 40(1), 59-81.

Esau, O. (2013). Preparing pre-service teachers as emancipatory and participatory action authors in the teacher education program. South African Journal of Education, 33(4), 1-10.http//doi.org/10.15700/201412171327

Falade, C. A. (2018). Impact of teachers' professional development on effective teaching of Business Studies at junior secondary schools in Ado local government area of Ekiti State. In M. M. Dichaba \& M. A. O. Sotayo (Ed.), Rethinking Teaching and Learning in the 21st Century, 276-290. Pretoria, South Africa: African Academic Research Forum.

Haigh, F., Kemp, L., Bazeley, P. (2019). Developing a critical realist informed framework to explain how the human rights and social determinants of health relationship works. BMC Public Health, 19, 15-71. https://doi.org/10.1186/s12889-019-7760-7

Halliday, A. J., Kern, M. L., Garrett, D. K., \& Turnbull, D. A. (2019). The student voice in wellbeing: A case study of participatory action research in positive education.

Educational Action Research, 27(2),173-196. https://doi.org/10.1080/09650792.2018.1436079

Hayat, A.A., Shateri, K., Amini, M. \& Shokrpour, N. 2020. Relationships between academic selfefficacy, learning-related emotions, and metacognitive learning strategies with academic performance in medical students: a structural equation model. BMC Medical Education, 20(76),1-11. https://doi.org/10.1186/s12909-020-01995-9

Hlalele, D. J. (2014). Creating sustainable rural learning ecologies in South Africa: Realities, lessons, and prospects. Journal of Human Ecology, 45(2), 101-110. https://doi.org/10.1080/09709274.2014.11906683

Hlalele, D. J. (2018). Higher education and the liberation struggle in the former Qwa-Qwa homeland. Journal of Contemporary History, 43(1),178-195. https://dx.doi. org/10.18820/24150509.

Hauge, K. (2019). Teachers' collective professional development in school: A review study. Cogent Education, 6(1):1-20. https://doi.org/10.1080/2331186X.2019.1619223. 
Molise, H. (2021). Pathways to Mitigate Challenges of Learner Academic Performance in a Grade 10 Economics Class in South Africa

Houdyshell, M., \& Ziegler, N. (2020). Graduate students share their experiences of building helping skills: A case study. Journal of Curriculum Studies Research.

https://doi.org/10.46303/jcsr.2020.4

Hsu, Y \& Lin, C. (2020). Evaluating the effectiveness of a preservice teacher technology training module incorporating SQD strategies. International Journal of Educational Technology in Higher Education, 17(31), 1-17. https://doi.org/10.1186/s41239-02000205-2

Hutton, M. (2020). Researching on the Edge: Emancipatory Praxis for Social Justice. European Journal of Marketing. https://doi.org/10.1108/EJM-02-2019-0150

Kgari-Masondo, C. \& Ngwenya, J. (2020). Lecturers' reflections on the teaching of social sciences in a multidisciplinary context at a university in South Africa. Reflective Practice in International and Multidisciplinary Perspectives, 21(2), 198-209.

Koenane, M. L. J. (2018). The role and significance of traditional leadership in the governance of modern democratic South Africa. Africa Review, 10(1), 58-71.

Laws, S., Harper, C. \& Marcus, R. (2003). Research for development. London: Sage.

Lane, R. \& Caldis, S. (2018). Participatory action research: A tool for promoting effective assessment and building the pedagogical content knowledge of secondary geography teachers. Geographical Education, 31, 16-30.

Mahlomaholo, M. G. (2014). Higher education and democracy: Analysing communicative action in the creation of sustainable learning environments. South African Journal of Higher Education, 28(2), 301-327.

Makoelle, T. M. (2013). Exploring teaching practices that are effective in promoting inclusion in South African secondary schools (unpublished doctoral thesis, University of the Free State, Bloemfontein, South Africa).

Malebese, M. L., Tlali, M. F., \& Mahlomaholo, S. (2019). A socially inclusive teaching strategy for fourth grade English (second) language learners in a South African school. South African Journal of Childhood Education, 9(1),1-8. https://doi.org/10.4102/sajce.V9i1.503.

Mashego, P. (2012). Plowing back to the future of communities: A culture of responsible citizenship and meaningful community social investments. Development Diaries, 1 , 41-47.

Molise, H. V. (2015). The use of a case study approach to mitigate challenges of learner academic performance in economics (unpublished Master's dissertation. University of the Free State, Bloemfontein, South Africa).

Molise, H, \& Hlalele, D. (2014). Using a case study as a teaching and learning strategy in the teaching of economics: A literature review. Mediterranean Journal of Social Sciences, 5(23), 999-1008.

Molinillo, S., Aguilar-Illescas, R., Anaya-Sánchez, R., \& Vallespín-Arán, M. (2018). Exploring the impacts of interactions, social presence, and emotional engagement on active collaborative learning in a social web-based environment. Computers \& Education, 12(3), 41-52. https://doi.org/10.1016/j.compedu.2018.04.012

Moloi, M.D. (2018). A professional curriculum practice of Grade 9 economic and management sciences teachers. Unpublished Masters Dissertation, University of the Free State, Bloemfontein. South Africa. 
Molise, H. (2021). Pathways to Mitigate Challenges of Learner Academic Performance in a Grade 10 Economics Class in South Africa

Msimanga, M.R. (2017). Teach and assess A strategy for effective teaching and learning in Economic and Management Sciences. (Unpublished doctoral thesis, University of the Free State, Bloemfontein, South Africa).

Myende, P.E. \& Nhlumayo, B.E. (2020): Enhancing parent-teacher collaboration in rural schools: parents' voices and implications for schools. International Journal of Leadership in Education, 1-26. https://doi.org/10.1080/13603124.2020.1731764

Myende, P.E. (2019). Creating functional and sustainable School-Community Partnerships: Lessons from three South African cases. Educational Management Administration \& Leadership, 47(6), 1001-1019.

Myende, P., \& Chikoko, V. (2014). School-university partnership in a South African rural context: Possibilities for an asset-based approach. Journal of Human Ecology, 46(3), 249-259.

Nja C. O. and Obi, J. J. (2019). Effect of Improvised Instructional Materials on Academic Achievement of SS1 Chemistry Students in Cross River State Nigeria. International Journal of Applied Research, 5(7), 444-448

Nja, C. O. Cornelius-Ukpepi, B. U. and Orim, R. E. (2019) Effect of Simulation instructional method on undergraduate Chemistry Education students' academic performance in Sodium reactions. European Journal of Scientific Research, 15(1), 6-12.

Nkoane, M. M. (2012). Critical emancipatory research for social justice and democratic citizenship. Perspectives in Education, 30(4), 98-104.

Ntibi. J.E.E and Neji, H.A. (2018). Effect of problem-solving method of teaching on performance in physics and chemistry in Calabar municipality, cross river state, Nigeria. Global Scientific Journal, 6(2), 121-140. https://doi.org/10.26803/ijlter.19.5.10

Pillay, A. (2015). Using participatory research with student teachers in a South African English education lecture-room: Methodological implications. South African Journal of Education, 61, 75-91.

Pillay, A. (2018). Enabling agency through participatory action research in an honors-level post-graduate class in a school of education. South African Journal of Higher Education, 32(6), 469-482. http//doi.org/10.20853/32-6-2940

Udvarhelyi, E.T. (2020). Participatory action research as political education, Action Learning. Research and Practice, 17,1, 24-33. https://doi.org/10.1080/14767333.2020.1712839

Risa, T. \& Pupung, P. (2019). The Influence of Interest and Motivation on College Students' Language and art Appreciation Learning Outcomes. International Journal of Education, 11(2),130-135.

Sahito, Z. \& Vaisanen, P. (2018). The Perception and Experience of Teacher Educators about their Motivation: A Case Study Approach. Journal of Language Teaching and Research, 9, 480-490.

Samadi, M. (2021). The Effect of a Principal's Instructional Supervisory Practice on Teacher Satisfaction in the Religious Ministry Schools of Semarang, Indonesia. Journal of Social Studies Education Research, 12(1), 194-215.

Shangase, B. B. (2013). Strategies for the implementation of further education and training learner attainment plan (unpublished Master's dissertation, University of the Free State, Bloemfontein, South Africa). 
Molise, H. (2021). Pathways to Mitigate Challenges of Learner Academic Performance in a Grade 10 Economics Class in South Africa

Soltero Lopez, A., \& Lopez, P. (2020). Expanding Our Reach: Cross-Institutional Collaborations and Teacher Preparation in Hispanic Serving Institutions. Journal of Culture and Values in Education, 3(1), 120-135. https://doi.org/10.46303/jcve.03.01.8

Stone, J.R. (2017) Introduction to Pathways to a Productive Adulthood: The Role of CTE in the American High School. Peabody Journal of Education, 92(2),155-165. https://doi.org/10.1080/0161956X.2017.1302207

Tondeur, J., Aesaert, K., Prestridge, S., \& Consuegra, E. (2018). A multilevel analysis of what matters in the training of preservice teacher's ICT competencies. Computers \& Education, 12(2), 32-42. https://doi.org/10.1016/j.compedu.2018.03.002

Trigueros, R., Aguilar-Parra, J.M., Lopez-Liria, R., Cangas, A.J., González, J.J. \& Álvarez, J.F. (2020). The Role of Perception of Support in the Class on the Students' Motivation and Emotions: The Impact on Metacognition Strategies and Academic Performance in Math and English Classes. Frontiers in Psychology, 10, 27-94. http//doi: 10.3389/fpsyg.2019.02794

Tshelane, M. D. (2013). Participatory action research and the construction of academic identity among postgraduate students. Journal of Transdisciplinary Research, 9(3), 401-429. https://hdl.handle.net/10520/EJC149276

Tsotetsi, C. T. (2013). The implementation of professional teacher development policies: A continuing education perspective (Unpublished doctoral thesis, University of the Free State, Bloemfontein, South Africa).

Tsotetsi, C. T., \& Mahlomaholo, S. (2015). Exploring strategies to strengthen the continuing professional development of teachers in rural South Africa. Council for the Development of Social Science Research in Africa, 13(1\&2), 45-73.

Van Wyk, J \& Haffejee (2017). Benefits of Group Learning as a Collaborative Strategy in a Diverse Higher Education Context. International Journal of Educational Sciences, 18 (1-3), 158-163. http://dx.doi.org/10.1080/09751122.2017.1305745

Van Wyk, M. M. (2017). Exploring Student Teachers' Views on e-Portfolios as an Empowering Tool to Enhance Self- Directed Learning in an Online Teacher Education Course. Australian Journal of Teacher Education, 42(6). http://dx.doi.org/10.14221/ajte.2017v42n6.1

Van Wyk, M., \& Alexander, G. (2010). Do teaching methods presented by the National Council on Economics Education (USA) enhance trainers' learning capacity in economics education? A South African perspective. Journal of Social Science, 23(3),159-169.

Warman, C. (2021). Establishing the Governmental Policy to Promote Engagement within the Inclusive Education System in Indonesia. Journal of Social Studies Education Research, 12(1), 124-148.

Wright, P. 2020. Transforming mathematics class practice through participatory action research. Journal of Mathematics Teacher Education. https://doi.org/10.1007/s10857019-09452-1 